\title{
Editor's Notes
}

Russell's Favourite Poetry

SCarl Spadoni blogged this description (with a photograph) of a new acquisition in the McMaster Library. "Bertie Russell attracted, frightened me; but everything he said had an intense, piercing, convincing quality.' This was Lady Ottoline Morrell's first impression of Bertrand Russell when they met in London at a dinner party in March I9II. She was an English aristocrat and the hostess of the Garsington circle with luminaries such as Lytton Strachey, T. S. Eliot, D. H. Lawrence, Herbert Asquith, and Virginia Woolf. Saddled in an unhappy marriage with his first wife, Russell quickly fell in love with Ottoline. Between I9II and I938, the year of Ottoline's death, [they exchanged 3,500] remarkable, insightful letters. In the last few years Ottoline's library and a number of her letters have been selling on eBay and at auction.... Our greatest acquisition from this source is a magnificent commonplace poetry book, bound in dark brown, tooled leather (REC. ACQ. 1529). Ottoline has jotted down a few quotations from Santayana and Milton ... followed by transcriptions in Russell's best hand of more than 30 of his favourite poems, originally penned by G. Lowes Dickinson, Blake, Shakespeare, Shelley, Matthew Arnold, and Leopardi. Undoubtedly, Russell and Ottoline compiled this commonplace book at the zenith of their relationship. It is a symbolic testament to their love affair and her enduring influence" (http://library.mcmaster.ca). Russell also wrote poetry of his own for Morrell, but these were 30 works of unsurpassed descriptive power of the poetical worlds of Love, Time and Nature. The last line, from Blake, was one that Russell was to quote again: "Love, sweet love, was thought a crime."

SFrancis A. Boyle gave the Russell Peace Lectures for 2007. His

Peace Lectures topic was "The Legacy of Bertrand Russell: Principle confronting Power”. See www.humanities.mcmaster.ca/ $\sim$ peace/francis.html. IAn outstanding long letter, just acquired, advising Francis E. Other Maitland on educating his son in science, dates from July 1927, Acquisitions just before Beacon Hill School opened. (1927 happens to be the test year for the Collected Letters project, so another letter from that year is especially welcome.) In the letter Russell recommends that Maitland read up the first three Parts of Newton's Principia. His boy could start on J. Arthur Thomson's Outline of Science. Another unusual letter is to a child, namely Julian Morrell, in which Russell encloses a "pretty" Japanese stamp and 
some "less interesting" Indian ones. From the same auction as this letter we managed a transcription of a reduced and faint photo in the sales catalogue of one to Philip Morrell in I9I6. This letter concerns Russell's War Office case-as well as the storage of his greatcoat at Garsington. A third new letter concerns there being no "fuss" over Marriage and Morals until the CCNY case in I940.

IA new, very long I9I6 letter to the editor on the pacifists has

\section{Collected}

Papers come to light. Too late for Volume 13 of the Collected Papers, it will appear in the catch-up volume at the end. Here is an excerpt: "These men believe, rightly or wrongly, that the evils of militarism and the atrocities that the war has brought forth will never be extirpated by fighting. They believe that militarism can only be destroyed by pacifism, and that hate can only be killed by love. There were such men in Germany. It has been reported that many have been shot in that country. But no punishment can prove them mistaken; punishment can only prove their sincerity in the eyes of a doubting public. They believe that, with faith and courage, passive resistance is more unconquerable than bayonets; and if the authorities choose to put them to the test, they are prepared to demonstrate the truth of their belief by their own endurance." The source is The Freethinker, 36 (I4 May I916): 310, found extracted in Jim Herrick's Vision and Realism (1982). The following works have been announced: Erik J. Wielenberg, Forthcoming God and the Reach of Reason: C.S. Lewis, David Hume, and Books

Bertrand Russell (New York: Cambridge U. P.); Burton Feldman, II2 Mercer Street: Einstein, Russell, Gödel, Pauli, and the End of Innocence in Science (New York: Arcade); David Mills Daniel, Briefly: Russell's The Problems of Philosophy (London: SCM P.); Ray Perkins, Jr. Russell: a Guide for the Perplexed (London: Continuum); and Dale Jacquette and Nicholas Griffin, eds., Russell vs. Meinong: the Legacy of "On Denoting", a selection for Routledge of fifteen more papers from the Russell Research Centre's conference in May 2005, when it and the Bertrand Russell Society met simultaneously.

INewly published are: Esther Ramharter and Georg Rieckh, Die

New Principia Mathematica — aufden Punktgebracht (Vienna: öbvhpt Books

Verlagsgesellschaft, 2007), and Huw Price and Richard Corry, eds., Causation, Physics, and the Constitution of Reality: Russell's Republic Revisited (Oxford: Clarendon P., 2007).

TThe drafting of the electronic catalogue of Russell's vast corre-

BRACERS spondence continues its too, too slow approach to completion. It was used recently to answer important queries on race, despite the caveat of incompleteness. The total number of entries is 108,935, publicly searchable at http://bracers.mcmaster.ca.

IRussell-1 is a discussion forum managed by Andrew Bone for Russell-1 the benefit of Russell Studies. Visit http://mailman.mcmaster.ca/ mailman/listinfo/russell-1. All the messages are searchable. 